\title{
Pituitary adenylate cyclase-activating polypeptide, interleukin-6 and glucocorticoids regulate the release of vascular endothelial growth factor in pituitary folliculostellate cells
}

\author{
J Gloddek, U Pagotto, M Paez Pereda, E Arzt ${ }^{1}$, G K Stalla and \\ U Renner
}

Max Planck Institute of Psychiatry, Department of Endocrinology, Kraepelinstr. 10, D-80804 Munich, Germany

${ }^{1}$ Lab. Fisiologia y Biologia Molecular, FCEN, Universidad de Buenos Aires and CONICET, Ciudad Universitaria, Pabellon II, 1428 Buenos Aires, Argentina

(Requests for offprints should be addressed to $U$ Renner)

\begin{abstract}
There is increasing evidence that hormones play an important role in the control of endothelial cell function and growth by regulating the production of vascular endothelial growth factor (VEGF). VEGF regulates vascular permeability and represents the most powerful growth factor for endothelial cells. In the normal anterior pituitary, VEGF has been detected only in folliculostellate (FS) cells. In the present study, the regulation of the release of VEGF from FS-like mouse TtT/GF cells, and from FS cells of rat pituitary monolayer cell cultures was investigated using a specific VEGF ELISA. Basal release of VEGF was demonstrated in cultures of both TtT/GF cells and rat pituitary cells. Interestingly, the VEGF secretion was stimulated by both forms of pituitary adenylate cyclase-activating polypeptide (PACAP-38 and PACAP-27), indicating that this hypothalamic peptide regulates endothelial cell func-
\end{abstract}

tion and growth within the pituitary. VEGF secretion was also stimulated by interleukin-6 (IL-6) whereas basal, IL-6- and PACAP-stimulated secretion was inhibited by the synthetic glucocorticoid dexamethasone. The inhibitory action of dexamethasone was reversed by the glucocorticoid receptor antagonist RU486, suggesting that in FS cells functional glucocorticoid receptors mediate the inhibitory action of glucocorticoids on the VEGF secretion. The endocrine and auto-/paracrine control of VEGF production in pituitary FS cells by PACAP, IL-6 and glucocorticoids may play an important role both in angiogenesis and vascular permeability regulation within the pituitary under physiological and pathophysiological conditions.

Journal of Endocrinology (1999) 160, 483-490

\section{Introduction}

Vascular endothelial growth factor (VEGF) is one of the most important factors for the development, growth and function of the endothelium (Dvorak et al. 1995, Klagsbrun \& D'Amore 1996, Ferrara \& Davis-Smyth 1997). VEGF is part of a family of structurally homologous peptides, including placenta-derived growth factor, VEGF-B, VEGF-C and VEGF-related protein (Ferrara \& Davis-Smyth 1997). Different isoforms of VEGF, which can be distinguished according to the number of amino acid residues, are produced by alternative splicing. Human (h) VEGF $_{121}$, hVEGF $_{145}$ and hVEGF $_{165}$ (corresponding to mouse $(\mathrm{m}) \mathrm{VEGF}_{120}$ and $\left.\mathrm{mVEGF}_{164}\right)$ are secreted isoforms of VEGF, whereas hVEGF 189 , (corresponding to $\mathrm{mVEGF}_{188}$ ) and $\mathrm{hVEGF}_{206}$ are membrane-associated isoforms (Ferrara \& Davis-Smyth 1997). Among the VEGF isoforms, all of which are biologically active, $\mathrm{hVEGF}_{165}$ $\left(\mathrm{mVEGF}_{164}\right)$ is predominantly produced (Wilting \& Christ 1996, Ferrara \& Davis-Smyth 1997). VEGF stimu- lates endothelial cell proliferation by paracrine and juxtacrine mechanisms acting via two types of tyrosine kinase receptors, flk-1/KDR and flt-1 which are predominantly expressed on endothelial cells (Millauer et al. 1993, Mustonen \& Alitalo 1995, Klagsbrun \& D'Amore 1996, Ferrara \& Davis-Smyth 1997). Apart from its growth stimulatory activity, VEGF is an important regulator of endothelial cell function by enhancing the vascular permeability (Dvorak et al. 1995).

Although pituitary folliculostellate (FS) cells were the first normal cell type in which VEGF was detected (Leung et al. 1989, Ferrara \& Henzel 1989), little attention has been paid to the regulation of the VEGF release from these cells and its importance for pituitary endothelial cells. FS cells represent about 5 to $10 \%$ of the anterior pituitary cells (Rinehart \& Farquhar 1953) and are multifunctional (Allaerts et al. 1990). The FS cell is the only cell type within the normal pituitary that produces VEGF (Jabbour et al. 1997). This cell type also synthesizes other angiogenesis-regulating substances such as basic 
fibroblast growth factor, leukemia inhibitory factor, and interleukin-6 (IL-6) (Ferrara et al. 1987, 1992, Vankelecom et al. 1989).

Several years ago, an FS-like mouse pituitary cell line (TtT/GF cells) was cloned that exhibits most characteristics of normal FS cells (Inoue et al. 1992). In the present study, we have investigated whether TtT/GF cells also produce VEGF and can therefore be used as a model to study the regulation of VEGF secretion. In both TtT/GF cells and in normal FS cells of rat pituitary cell cultures we tested whether substances that are known, or assumed to act on FS cells (Carmeliet et al. 1991, Matsumoto et al. 1993, Renner et al. 1997), such as pituitary adenylate cyclase-activating polypeptide (PACAP-38, PACAP-27), vasoactive intestinal peptide (VIP), IL-6 and glucocorticoids, represent physiological regulators of the VEGF release.

\section{Materials and Methods}

\section{Materials}

Cell culture materials and reagents were obtained from Gibco (Karlsruhe, Germany), Falcon (Heidelberg, Germany), Nunc (Wiesbaden, Germany), Seromed (Berlin, Germany), Flow (Meckenheim, Germany) and Sigma Chemicals (St Louis, MO, USA). Mouse IL-6 (mIL-6) was obtained from Boehringer Mannheim (Mannheim, Germany). PACAP-38, PACAP-27 and VIP were purchased from Bachem (Bubendorf, Switzerland). Dexamethasone was obtained from Sigma Chemicals and RU486 from Roussel (Romainville, France).

\section{Cell culture}

TtT/GF cells were kindly provided by Professor Kinji Inoue from the Department of Regulation Biology, Saitama University, Urawa, Japan. The cells were grown in 48 multi-well plates at $37^{\circ} \mathrm{C}$ and $5 \% \mathrm{CO}_{2}$ in Dulbecco's modified Eagle's medium ( $\mathrm{pH} 7 \cdot 3$ ) supplemented with $2 \%$ fetal calf serum (FCS), $2 \cdot 2 \mathrm{~g} / 1 \mathrm{NaHCO}_{3}$, $10 \mathrm{mM}$ HEPES, $2 \mathrm{mM}$ glutamine, $2.5 \mathrm{mg} / \mathrm{l}$ amphotericin $\mathrm{B}, 10^{5} \mathrm{U} / 1$ penicillin-streptomycin, $5 \mathrm{mg} / 1$ insulin, $5 \mathrm{mg} / 1$ transferrin, $20 \mathrm{mg} / 1$ sodium selenite and $30 \mathrm{pM}$ tri-iodothyronine. TtT/GF cells were cultured until they were confluent. After a complete monolayer was formed (approximately 70000 cells per well in 48-well plates), cells did not grow further, as described previously (Renner et al. 1997). The monolayer was washed with PBS and serum-free culture medium was added for $24 \mathrm{~h}$ to wash out any remaining serum. The cells were then washed again with PBS and the stimulation was performed in serum-free culture medium. With the exception of time-course studies cells were stimulated for $24 \mathrm{~h}$.

Rat pituitary monolayer cell cultures, generated as described previously (Renner et al. 1995), were cultivated in the same medium as $\mathrm{TtT} / \mathrm{GF}$ cells but supplemented with $10 \%$ FCS. The initial density of rat pituitary cells was 100000 cells per well in 48-well plates. After an initial attachment period of $48 \mathrm{~h}$ and a serum washout period of $24 \mathrm{~h}$, the cells were stimulated in serum-free medium for $24 \mathrm{~h}$.

Before and after the stimulation period, cell viability and numbers were routinely monitored to ensure that these parameters did not change during the experiment. Cell viability was determined microscopically after ethidium bromide/acridine orange staining. Cell numbers were determined with an adapted Coulter counter (Renner et al. 1995).

For the determination of the intracellular VEGF content, TtT/GF cells were washed twice with PBS and lysed by three freeze-thaw cycles in PBS containing $0 \cdot 1 \%$ BSA and $400 \mathrm{kIU} / \mathrm{ml}$ aprotinin (Bayer, Leverkusen, Germany). The lysates were centrifuged to remove cell debris and the supernatants were assayed for VEGF by ELISA.

\section{Stimulation and VEGF measurement}

Dexamethasone, IL-6, PACAP-38, PACAP-27 and VIP were added to the cell cultures alone or in combination at various concentrations as indicated. After $24 \mathrm{~h}$ the cell culture supernatants were harvested at various timeintervals in the case of time-course studies, or after $24 \mathrm{~h}$ in the case of the dose-response studies. VEGF was measured by ELISA (R\&D Systems, Minneapolis, MN, USA) which recognizes the predominantly produced mouse VEGF164 isoform, but can also be used to detect the corresponding rat VEGF (cross-reactivity $>95 \%$ ). The detection limit of the assay was $3 \mathrm{pg} / \mathrm{ml}$ VEGF. The intra-assay coefficient of variation was $4 \cdot 7 \%$, and the interassay coefficient of variation was $6 \cdot 4 \%$.

\section{Statistics}

Each of the experiments was repeated at least three times. The individual experiments were performed with quadruplicate wells. ANOVA in combination with Scheffe's test was used for statistics. The data are expressed as means \pm S.D.

\section{Results}

\section{VEGF secretion in TtT/GF cells}

In lysates of the TtT/GF cells, VEGF protein could be detected by ELISA. The concentrations of soluble VEGF in extracts of TtT/GF cells varied between 5 and $6 \mathrm{pg} /$ 100000 cells.

A basal release of VEGF was measured in confluent monolayer cultures of TtT/GF cells. The accumulation of VEGF in the supernatants was linear over a period of $72 \mathrm{~h}$ 


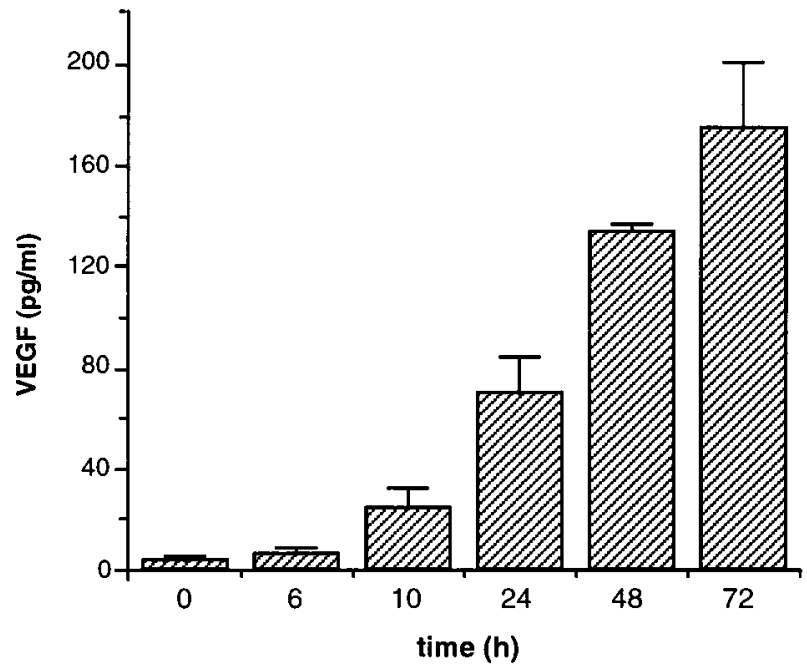

Figure 1 Basal release of VEGF from TtT/GF cells during a 72-h incubation period. Values are means \pm S.D.

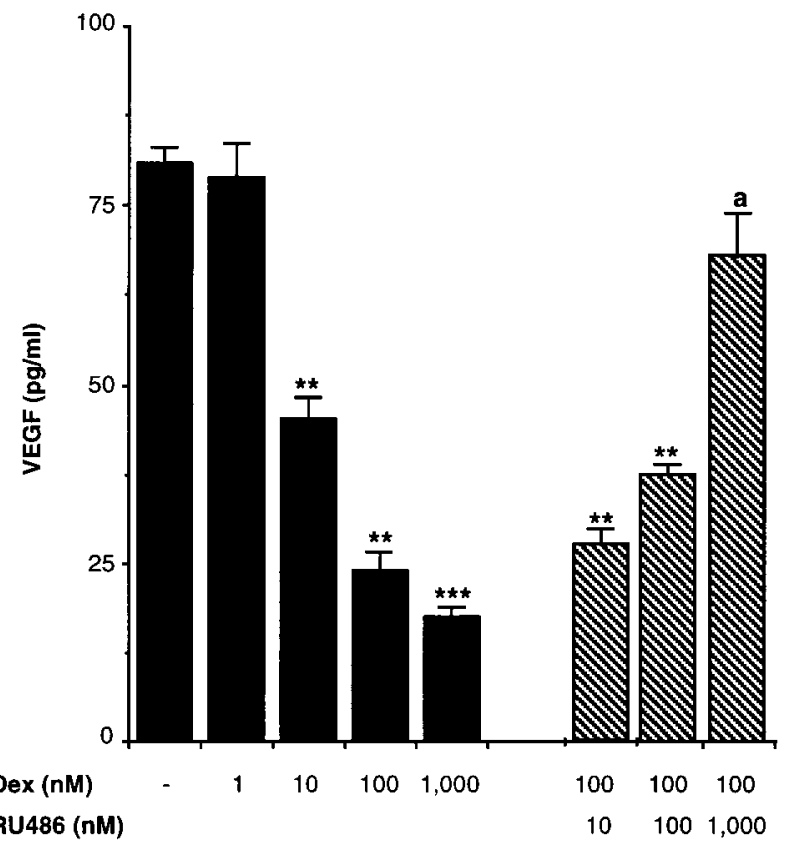

Figure 2 Inhibition of the basal VEGF production of TtT/GF cells by dexamethasone (Dex) and its reversion by RU486. ${ }^{* *} P<0 \cdot 01$, ${ }^{* * *} P<0.001$ vs basal; a, not significant vs basal secretion. Values are means \pm S.D.

during which no alterations in cell viability or cell number could be observed (Fig. 1). The accumulation of VEGF shown in Fig. 1 corresponds to a VEGF production rate of 106 pg VEGF/100 000 cells per $24 \mathrm{~h}$.

The synthetic glucocorticoid dexamethasone suppressed the basal release of VEGF in a dose-dependent manner (Fig. 2). The dexamethasone-induced inhibition was reversed by the glucocorticoid receptor antagonist

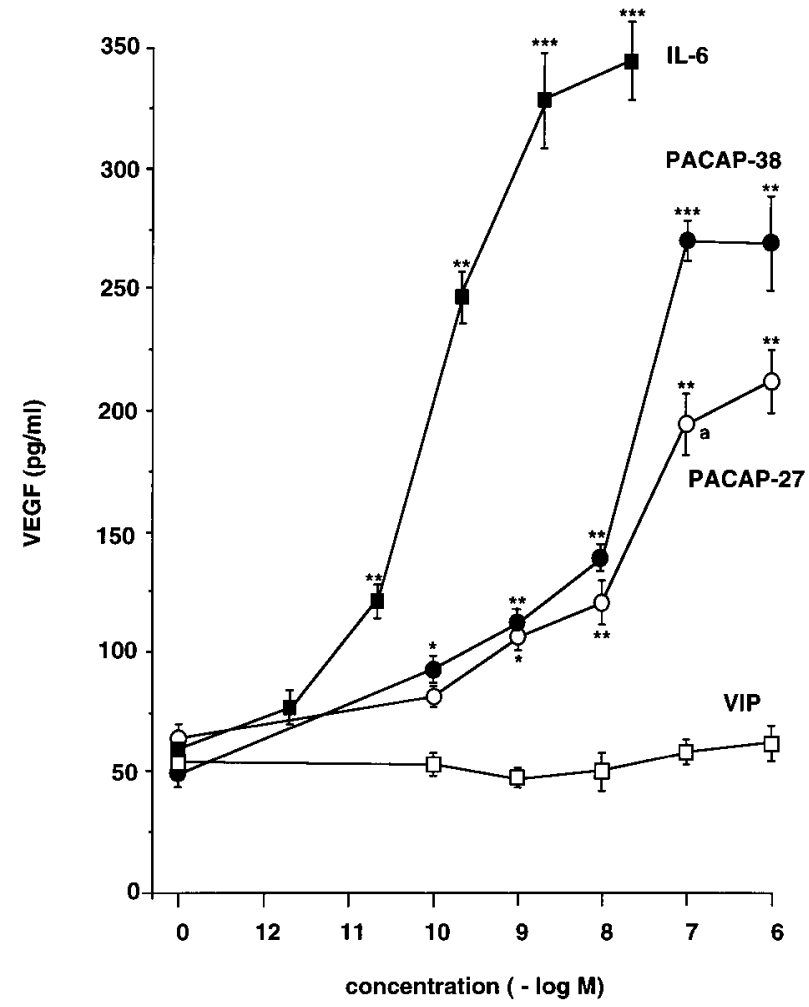

Figure 3 Effect of mIL-6, PACAP-38, PACAP-27 and VIP on the VEGF release from TtT/GF cells during a 24-h incubation period. ${ }^{*} P<0.05,{ }^{* *} P<0.01,{ }^{* * *} P<0.001$ vs basal secretion; $a, P<0.05$ vs $100 \mathrm{nM}$ PACAP-38. Values are means \pm S.D.

RU486. Thus, functional glucocorticoid receptors seem to be present in TtT/GF cells that mediate the inhibitory effect of dexamethasone on the VEGF secretion.

Interleukin-6, PACAP-38, and PACAP-27 dosedependently stimulated the release of VEGF from TtT/GF cells (Fig. 3). Maximal stimulatory effects were achieved at concentrations of $100 \mathrm{nM}$ PACAP-38 and PACAP-27 or $5 \mathrm{nM}$ IL-6. Only at a concentration of $100 \mathrm{nM}$ was PACAP-38 significantly more effective than PACAP-27. Although the use of tenfold increments was critical, we calculated the approximate $\mathrm{ED}_{50}$ values for IL-6, PACAP-38 and PACAP-27 to obtain information about the relative VEGF-stimulating potency of these substances. From three different dose-response experiments, $\mathrm{ED}_{50}$ values of $105 \pm 42 \mathrm{pM}, 45 \pm 13 \mathrm{nM}$ and $58 \pm 19$ nM were calculated for mIL-6, PACAP-38 and PACAP-27 respectively. VIP, a peptide similar to PACAP, had no effect on the VEGF release, suggesting that the stimulatory action of PACAP-38 and PACAP-27 on the VEGF secretion is mediated by the PACAPspecific PACAP type-I receptor.

Time-course studies of the inhibitory and stimulatory action of the substances mentioned showed significant differences between stimulated and basal VEGF secretion 


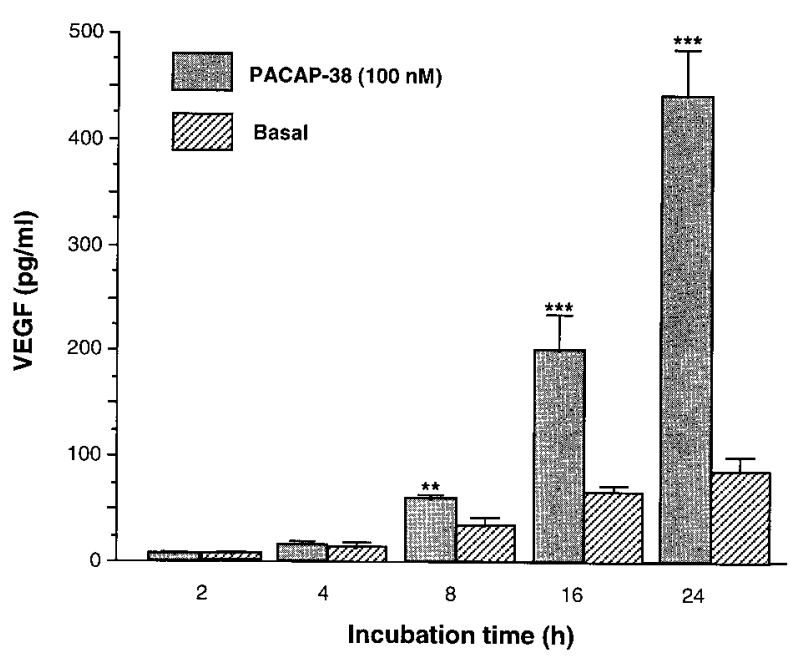

Figure 4 Time-course of the stimulatory action of PACAP-38 on the VEGF secretion of TtT/GF cells. No effect of PACAP in comparison to basal VEGF secretion was observed during the first $4 \mathrm{~h}$ of the stimulation period. ${ }^{* *} P<0 \cdot 01,{ }^{* *} P<0.001 \mathrm{vs}$ basal secretion. Values are means \pm S.D.

only after an incubation period of $8 \mathrm{~h}$. A representative experiment for PACAP-38 is shown in Fig. 4; similar time-course patterns were also measured for the stimulatory effects of IL-6 and PACAP-27 and the suppressive action of dexamethasone (data not shown).

Dexamethasone not only inhibited the basal release of VEGF but also suppressed the stimulatory action of IL-6 and PACAP on the VEGF release. This inhibitory action of dexamethasone was completely reversed by RU486 (Fig. 5).

\section{VEGF secretion in rat pituitary monolayer cell cultures}

An accumulation of VEGF could also be measured in the supernatants of rat pituitary monolayer cultures in which cells were cultivated at a density of 100000 cells/ $\mathrm{cm}^{2}$. Interleukin-6, PACAP-38 and PACAP-27 dosedependently stimulated the basal release of VEGF from normal rat FS cells (Fig. 6), whereas VIP had no effect. The $\mathrm{ED}_{50}$ values of mIL-6, PACAP-38 and PACAP-27 were $730 \pm 175 \mathrm{pM}, 32 \pm 18 \mathrm{nM}$ and $15 \pm 7 \mathrm{nM}$ respectively. In contrast to $\mathrm{TtT} / \mathrm{GF}$ cells, there was no significant difference in the VEGF-stimulatory potency of PACAP-38 and PACAP-27 at any concentration tested. Dexamethasone inhibited both the basal and the stimulated VEGF secretion, and RU486 reversed this inhibition (Fig. 7). In none of the experiments with rat pituitary cells did changes in the VEGF production result from changes in cell number or cell viability. Almost no fibroblasts, as identified by their typical spindle-formed morphology, could be detected microscopically in the pituitary cell cultures after the experiments. In summary, the VEGF

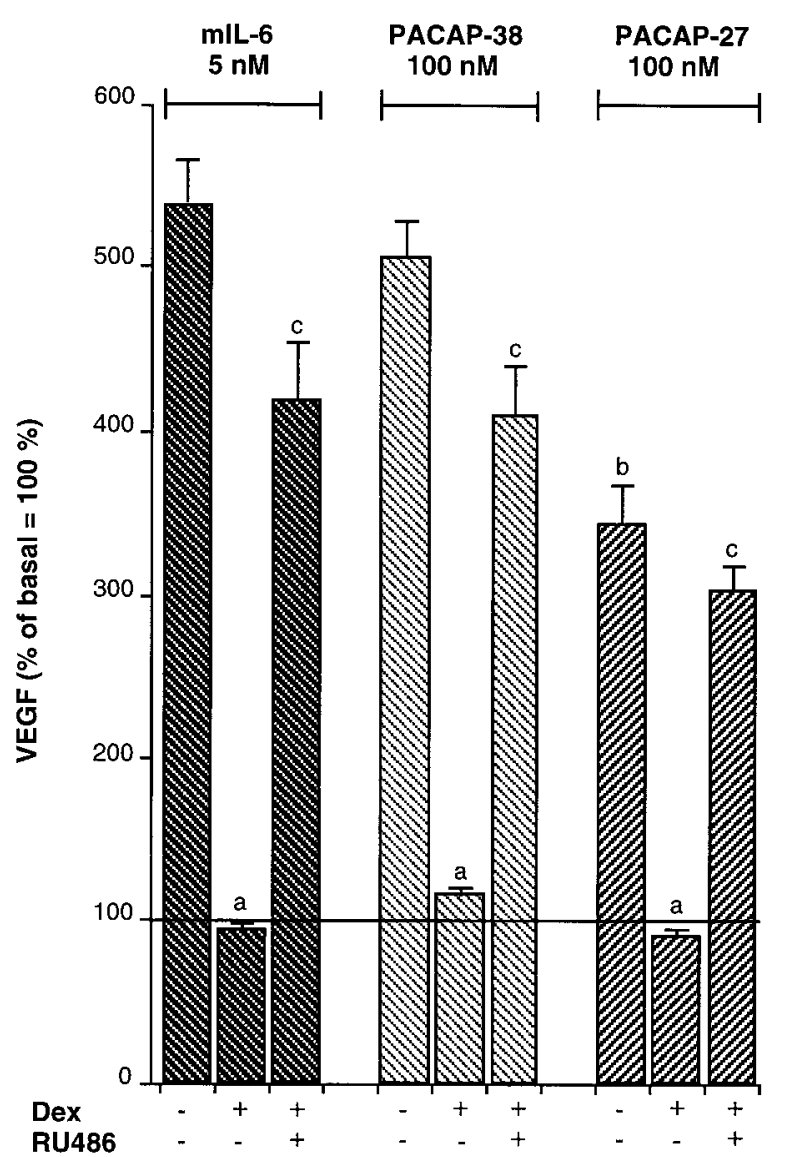

Figure 5 Effect of dexamethasone (Dex) on the mIL-6-, PACAP-38and PACAP-27-stimulated VEGF secretion of TtT/GF cells. The inhibitory action of Dex (100 nM) on the stimulated VEGF secretion could be reversed by RU486 $(1 \mu \mathrm{M})$. As the data were obtained from various experiments in which slightly different basal VEGF values were obtained, the basal secretion is set at $100 \%$ and differences are expressed in \% of basal. a, $P<0.001$ vs stimulated VEGF secretion; $b, P<0 \cdot 01$ vs PACAP-38-stimulated VEGF secretion; c, not significant vs stimulated VEGF secretion. Values are means \pm S.D.

production of rat pituitary monolayer cell cultures is regulated in an identical manner as in mouse FS-like TtT/GF cells.

\section{Discussion}

VEGF, probably the most important regulator of endothelial cell growth and function, is secreted by various normal and neoplastic cell types and acts in a paracrine manner to stimulate the proliferation and permeability of endothelial cells (Dvorak et al. 1995, Klagsbrun \& D'Amore 1996, Ferrara \& Davis-Smyth 1997). In the normal pituitary, VEGF expression was only found in FS cells (Jabbour et al. 1997) suggesting a central role for this 


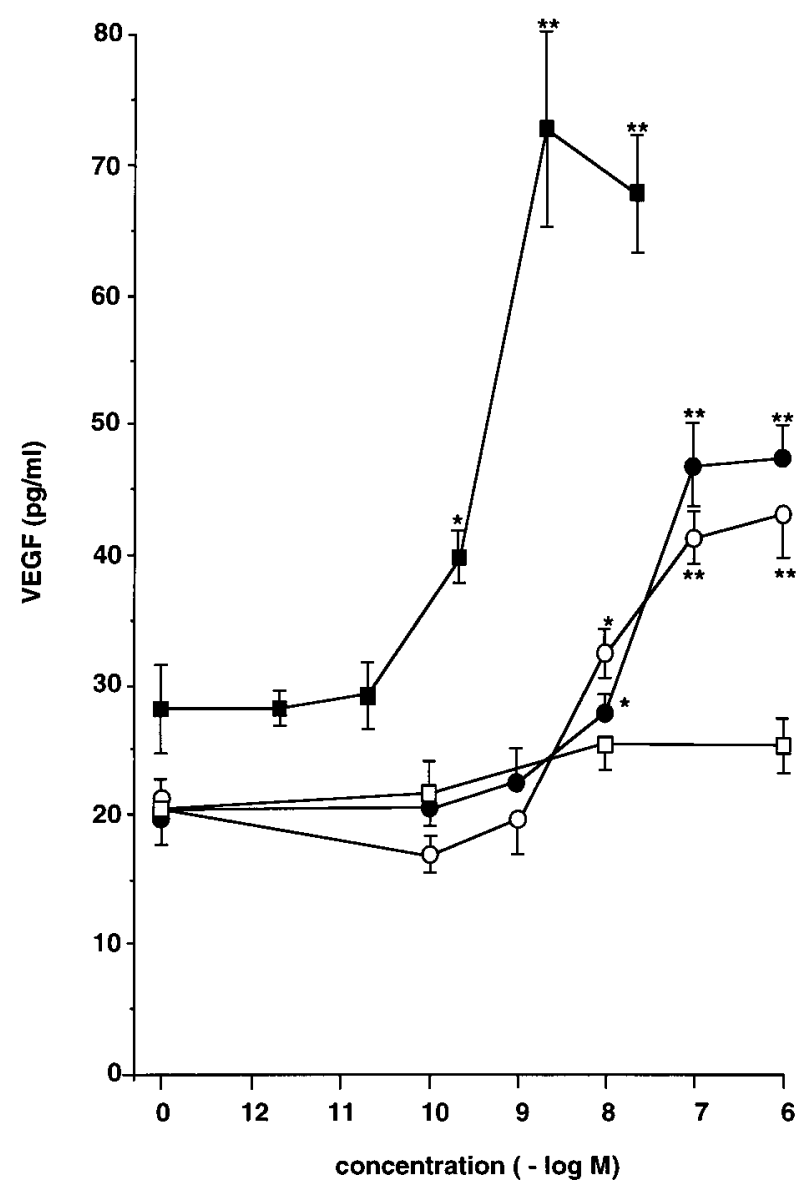

Figure 6 Effect of mIL-6 (ם), PACAP-38 (- P), PACAP-27 $(\bigcirc)$ and VIP $(\square)$ on VEGF release from rat pituitary cells during a $24-\mathrm{h}$ incubation period. ${ }^{*} P<0 \cdot 05,{ }^{* \star} P<0 \cdot 01,{ }^{* *} P<0 \cdot 001 \mathrm{vs}$ basal secretion. Values are means \pm S.D.

cell type in the regulation of angiogenesis and vascular permeability within the pituitary. The present study is the first in which the regulation of the release of VEGF from pituitary FS cells has been investigated. To this end, an FS-like pituitary cell line that contains and secretes VEGF was used as a model and the results were confirmed with normal rat pituitary cell cultures. In the latter, the basal VEGF production was less than in $\mathrm{TtT} / \mathrm{GF}$ cell cultures because only the subpopulation of FS cells secrete VEGF (Jabbour et al. 1997). Normal endocrine cells produce no VEGF (Jabbour et al. 1997) and in our experiments only a few contaminating fibroblasts were visible microscopically that could contribute to the VEGF production in the pituitary cell cultures.

Interestingly, we show that the hypothalamic factors PACAP-38 and PACAP-27, but not the closely related VIP, stimulate VEGF secretion. PACAP-38 and PACAP-27 are hypothalamic peptides that are potent stimulators of the cAMP production in pituitary cells

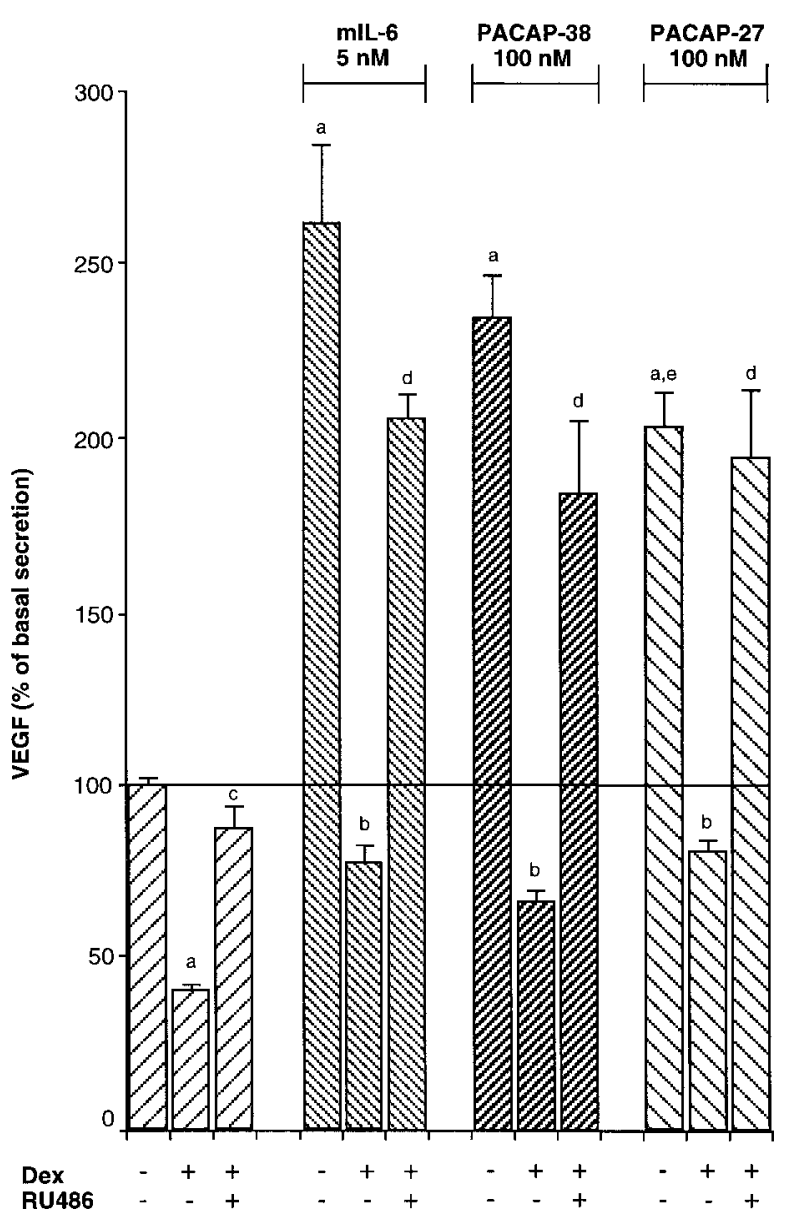

Figure 7 Accumulation of VEGF in rat pituitary monolayer cell cultures and alterations in response to dexamethasone (Dex), mIL-6, PACAP-38 and PACAP-27. Maximal effects from a series of dose-response studies (24-h incubation period) are summarized. As the basal VEGF production varied from 18 to $32 \mathrm{pg} / \mathrm{ml}$ VEGF in the different experiments, the results are expressed in $\%$ of basal secretion $(=100 \%)$. IL-6, PACAP-38 and PACAP-27 stimulated the VEGF release. Dexamethasone (100 nM) inhibited both basal and stimulated VEGF production, and RU486 $(1 \mu \mathrm{M})$ reversed this suppressive effect. $a, P<0.01$ vs basal VEGF secretion; $b, P<0.001$ vs mIL-6- and PACAP-stimulated VEGF secretion respectively; $c$, not significant vs basal VEGF secretion; $d$, not significant vs mIL-6- and PACAP-stimulated VEGF secretion respectively; e, not significant vs PACAP-38-stimulated VEGF secretion. Values are means \pm S.D.

(Miyata et al. 1989, Rawlings \& Hezareh 1996). The role of PACAP in the endocrine cells of the pituitary is still under discussion but it appears that PACAP is of considerable importance for the regulation of gonadotroph cell function (Rawlings \& Hezareh 1996). The observation that both forms of PACAP stimulate VEGF release in FS cells points to a completely new role for this peptide as an angiogenesis- or vascular permeability-regulating factor within the pituitary. As the closely related peptide VIP did not affect VEGF release the VEGF-stimulating effect of 
PACAP seems to be mediated via the PACAP type-I receptor, which has a high affinity for PACAP but not for VIP (Rawlings \& Hezareh 1996). Whether PACAP is involved in the regulation of endothelial cell function and growth of other PACAP receptor-expressing endocrine and neuroendocrine tissues remains to be studied.

Interleukin-6 is also a potent stimulator of the VEGF secretion in TtT/GF and normal FS cells. This cytokine not only reaches the pituitary via the circulation but is also intrinsically produced by FS cells (Vankelecom et al. 1989, Matsumoto et al. 1993, Renner et al. 1997). Therefore, IL-6 may stimulate the VEGF secretion within the pituitary in an autocrine manner. As PACAP stimulates the IL-6 secretion in FS cells (Matsumoto et al. 1993), the PACAP-induced effects on the VEGF release may be mediated via IL-6. This is however unlikely as VIP stimulates the secretion of IL-6 in FS cells to the same extent as PACAP (Matsumoto et al. 1993) but has no VEGF-stimulating potency. Moreover, as previously reported (Renner et al. 1997), the PACAP-induced maximum concentrations of about $0.05 \mathrm{nM}$ IL-6 in TtT/GF cell culture supernatants are too low to explain the strong stimulation of VEGF by PACAP. However, in the intact pituitary tissue with its small intercellular spaces, IL-6, released by PACAP, may reach concentrations that are high enough to enhance the direct effect of PACAP on the VEGF production.

In contrast to IL-6 and PACAP, dexamethasone suppressed the basal VEGF release from $\mathrm{TtT} / \mathrm{GF}$ and normal FS cells and also inhibited the IL-6- and PACAPstimulated VEGF production. This inhibitory effect on VEGF release was completely reversed by RU486, indicating that the inhibitory effects of glucocorticoids on VEGF production are mediated by functional glucocorticoid receptors expressed in FS cells. Thus, our observation confirms previous observations that FS cells contain glucocorticoid receptors that regulate the synthesis and/or release of FS cell-derived peptides (Carmeliet et al. 1991).

The discrepancy between the low intracellular level of soluble VEGF in TtT/GF cells (about 5 pg/100 000 cells) and the relatively high amount of VEGF secreted by $\mathrm{TtT} / \mathrm{GF}$ cells (approximately $100 \mathrm{pg} / 100000$ cells per $24 \mathrm{~h}$ ) suggests that the basal VEGF production is a consequence of a permanent de novo synthesis and subsequent release of VEGF. PACAP, IL-6 or dexamethasone do not rapidly alter VEGF secretion, indicating that these substances may not directly affect the release of VEGF from already existing VEGF pools in TtT/GF cells, but rather may stimulate or suppress de novo synthesis of VEGF. This has been shown in recent studies in which IL-6 was found to stimulate VEGF mRNA synthesis in various transformed cell lines (Cohen et al. 1996). Glucocorticoids inhibit VEGF mRNA expression in glioma cells (Heiss et al. 1996) and suppress VEGF synthesis induced by platelet-derived growth factor and platelet-activating factor in human pulmonary vascular smooth-muscle cells (Nauck et al. 1997). Estrogen (Cullinan-Bove \& Koos 1993, Shifren et al. 1996, Banerjee et al. 1997), progesterone (Sone et al. 1996) and thyrotropin (Soh et al. 1996) have also been shown to stimulate VEGF synthesis in normal and tumoral tissues and cell lines. This suggests that VEGF production is at least in part under hormonal control (Shweiki et al. 1993). Hypothalamic PACAP may fit into this concept as an endocrine-acting regulator of the intrapituitary VEGF production and may play a role in the development and maintenance of the portal blood vessel system and in the control of intrapituitary vascular permeability.

VEGF is probably the most important factor in angiogenesis (Ferrara \& Davis-Smyth 1997) and is essential for tumor growth and expansion (Kim et al. 1993, Claffey \& Robinson 1996). In pituitary adenomas, little is known about the role of VEGF in angiogenesis. Very recently it has been shown that VEGF is up-regulated in response to estrogen in as yet unidentified pituitary cells of Fischer 344 rats, indicating an early onset of angiogenesis during the development of estrogen-induced prolactinomas in these animals (Banerjee et al. 1997). Furthermore, it has been reported that TtT/GF cells are essential for pituitary tumor formation in nude mice, probably by supporting angiogenesis (Koyama et al. 1995). However, VEGF-producing FS cells are normally absent or rare within adenomas (Marin et al. 1992, Ueta et al. 1995), but it has been reported that a transition zone exists between the adenoma and the normal pituitary tissue that is extremely rich in FS cells (Marin et al. 1992, Farnoud et al. 1994). As many pituitary adenomas produce high levels of IL-6 (Jones et al. 1994) which probably supports both adenoma cell and FS cell growth (Arzt et al. 1993, Renner et al. 1997), we speculate that IL-6 may directly stimulate adenoma expansion as well as the formation of the transition zone. In parallel, IL-6 might enhance the release of VEGF from the FS cells of the transition zone inducing endothelial cell proliferation and the sprouting of vessels into the pituitary adenoma. In this model, glucocorticoids would suppress VEGF production and adenoma vessel formation which would limit the size of the pituitary tumor. Elevated serum levels of anti-angiogenic glucocorticoids could explain why in most cases corticotroph adenomas are microadenomas. It should be emphasized that the model of pituitary angiogenesis we propose is restricted to adenoma initiation processes and microadenomas. In macroadenomas, VEGF might also be produced by adenoma cells (Berkman et al. 1993), and other, still unknown mechanisms may regulate pituitary tumor angiogenesis.

In summary, we have demonstrated that the release of the most potent angiogenic factor, VEGF, from FS cells is stimulated by PACAP and IL-6, whereas it is inhibited by glucocorticoids. This endocrine and auto-/paracrine regulation of VEGF secretion may be essential for the development, maintenance and function of the pituitary 
vascular system, and may play a role in pituitary tumor angiogenesis as well.

\section{Acknowledgements}

We thank Dr Penny Largen for reviewing the manuscript for correct English. The work was supported by a grant from the DFG: Sta 285/7-3. E A is a recipient of a fellowship of the John Simon Guggenheim Memorial Foundation.

\section{References}

Allaerts W, Carmeliet P \& Denef C 1990 New perspectives in the function of pituitary folliculo-stellate cells. Molecular and Cellular Endocrinology 71 73-81.

Arzt E, Buric R, Stelzer G, Stalla J, Sauer J, Renner U \& Stalla GK 1993 Interleukin involvement in anterior pituitary cell growth regulation: effects of interleukin-2 (IL-2) and IL-6. Endocrinology 132 459-467.

Banerjee SK, Sarkar DK, Weston AP, De A \& Campbell DR 1997 Over expression of vascular endothelial growth factor and its receptor during the development of estrogen-induced rat pituitary tumors may mediate estrogen-initiated tumor angiogenesis. Carcinogenesis 18 1155-1161.

Berkman RA, Merrill MJ, Reinhold WC, Monacci WT, Saxena A, Clark WC, Robertson JT, Ali IU \& Oldfield EH 1993 Expression of the vascular permeability factor/vascular endothelial growth factor gene in central nervous system neoplasms. Journal of Clinical Investigation 91 153-159.

Carmeliet P, Vankelecom H, Van Damme J, Billiau A \& Denef C 1991 Release of interleukin-6 from anterior pituitary cell aggregates: developmental pattern and modulation by glucocorticoids and forskolin. Neuroendocrinology 53 29-34.

Claffey KP \& Robinson GS 1996 Regulation of VEGF/VPF expression in tumor cells: consequences for tumor growth and metastasis. Cancer Metastasis Reviews 15 165-176.

Cohen T, Nahari D, Weiss Cerem L, Neufeld G \& Levi B-Z 1996 Interleukin 6 induces the expression of vascular endothelial growth factor. Journal of Biological Chemistry 271 736-741.

Cullinan-Bove K \& Koos RD 1993 Vascular endothelial growth factor/vascular permeability factor expression in the rat uterus: rapid stimulation by estrogen correlates with estrogen-induced increases in uterine capillary permeability and growth. Endocrinology 133 829-837.

Dvorak HF, Brown LF, Detmar M \& Dvorak AM 1995 Vascular permeability factor/vascular endothelial growth factor, microvascular hyperpermeability, and angiogenesis. American Journal of Pathology 146 1029-1039.

Farnoud MR, Kujas M, Derome P, Racadot J, Peillon F \& Li JY 1994 Interactions between normal and tumoral tissues at the boundary of human anterior pituitary adenomas. Virchows Archiv A 424 75-82.

Ferrara N \& Henzel WJ 1989 Pituitary follicular cells secrete a novel heparin-binding growth factor specific for vascular endothelial cells. Biochemical and Biophysical Research Communications 161 851-858.

Ferrara N \& Davis-Smyth T 1997 The biology of vascular endothelial growth factor. Endocrine Reviews 18 4-25.

Ferrara N, Schweigerer L, Neufeld G, Mitchell R \& Gospodarowicz D 1987 Pituitary follicular cells produce basic fibroblast growth factor. Proceedings of the National Academy of Sciences of the USA 84 $5773-5777$.
Ferrara N, Winer J \& Henzel WJ 1992 Pituitary follicular cells secrete an inhibitor of aortic endothelial cell growth: identification as leukemia inhibitor factor. Proceedings of the National Academy of Sciences of the USA 89 698-702.

Heiss JD, Papavassiliou E, Merill MJ, Nieman L, Knightly JJ, Walbridge S, Edwards NA \& Oldfield EH 1996 Mechanism of dexamethasone suppression of brain tumor-associated vascular permeability in rats. Journal of Clinical Investigation 98 1400-1408.

Inoue $\mathrm{K}$, Matsumoto $\mathrm{H}$, Koyama C, Shibata K, Nakazato Y \& Ito A 1992 Establishment of a folliculo-stellate-like cell line from a murine thyrotropic pituitary tumor. Endocrinology 131 3110-3116.

Jabbour HN, Boddy SC \& Lincoln GA 1997 Flt-1 in the ovine pituitary gland: expression is independent of hypothalamic control. Molecular and Cellular Endocrinology 134 91-100.

Jones TH, Daniels M, James RA, Justice SK, McCorkle R, Price A, Kendall-Taylor P \& Weetman AP 1994 Production of bioactive and immunoreactive interleukin-6 (IL-6) and expression of IL-6 messenger ribonucleic acid by human pituitary adenomas. Journal of Clinical Endocrinology and Metabolism 78 180-187.

Kim K, Li B, Winer J, Armanini M, Gillett N \& Phillips H 1993 Inhibition of vascular endothelial growth factor-induced angiogenesis suppresses tumour growth in vivo. Nature 362 841-844.

Klagsbrun M \& D'Amore PA 1996 Vascular endothelial growth factor and its receptors. Cytokine and Growth Factor Reviews 7 259-270.

Koyama C, Matsumoto H, Sakai T, Wakabayashi K, Ito A, Couch EF \& Inoue K 1995 Pituitary folliculo-stellate-like cells stimulate somatotropic pituitary growth in nude mice. Endocrine Pathology 6 67-75.

Leung DW, Cachianes G, Kuang W-J, Goeddel DV \& Ferrara N 1989 Vascular endothelial growth factor is a secreted angiogenic mitogen. Science 246 1306-1309.

Marin F, Kovacs K, Stefaneanu L, Horvath E \& Cheng Z 1992 S-100 protein immunopositivity in human nontumorous hypophyses and pituitary adenomas. Endocrine Pathology 3 28-38.

Matsumoto H, Koyama C, Sawada T, Koike K, Hirota K, Miyake A, Arimura A \& Inoue K 1993 Pituitary folliculo-stellate-like cell line (TtT/GF) responds to novel hypophysiotrophic peptide (pituitary adenylate cyclase-activating peptide), showing increased adenosine $3^{\prime}, 5^{\prime}$-monophosphate and interleukin- 6 secretion and cell proliferation. Endocrinology 133 2150-2155.

Millauer B, Wizigmann-Voos S, Schnurch H, Martinez R, Moller NP, Risau W \& Ullrich A 1993 High affinity VEGF binding and developmental expression suggest flk-1 as a major regulator of vasculogenesis and angiogenesis. Cell 72 835-846.

Miyata A, Arimura A, Dahl R, Minamino N, Uehara A, Jiang L, Culler MD \& Coy DH 1989 Isolation of a novel 38 residuehypothalamic polypeptide which stimulates adenylate cyclase in pituitary cells. Biochemical and Biophysical Research Communications $164567-574$.

Mustonen T \& Alitalo K 1995 Endothelial receptor tyrosine kinases involved in angiogenesis. Journal of Cell Biology 129 895-898.

Nauck M, Roth M, Tamm M, Eickelberg O, Wieland H, Stulz P \& Perruchoud AP 1997 Induction of vascular endothelial growth factor by platelet-activating factor and platelet-derived growth factor is downregulated by corticosteroids. American Journal of Respiratory Cell Molecular Biology 16 398-406.

Rawlings SR \& Hezareh M 1996 Pituitary adenylate cyclaseactivating polypeptide (PACAP) and PACAP/vasoactive intestinal polypeptide receptors: actions on the anterior pituitary gland. Endocrine Reviews 17 4-29.

Renner U, Newton CJ, Pagotto U, Sauer J, Arzt E \& Stalla GK 1995 Involvement of interleukin-1 and interleukin-1 receptor antagonist in rat pituitary cell growth regulation. Endocrinology 136 3186-3193.

Renner U, Gloddek J, Arzt E, Inoue K \& Stalla GK 1997 Interleukin-6 is an autocrine growth factor for folliculostellate-like 
TtT/GF mouse pituitary tumor cells. Experimental and Clinical Endocrinology and Diabetes 105 345-352.

Rinehart JF \& Farquhar MG 1953 Electron microscopic studies of the anterior pituitary gland. Journal of Histochemistry and Cytochemistry 1 93-113.

Shifren JL, Tseng JF, Zaloudek CJ, Ryan IP, Meng YG, Ferrara N, Jaffe RB \& Taylor RN 1996 Ovarian steroid regulation of vascular endothelial growth factor in the human endometrium: implications for angiogenesis during the menstrual cycle and in the pathogenesis of endometriosis. Journal of Clinical Endocrinology and Metabolism $\mathbf{8 1}$ 3112-3118.

Shweiki D, Itin A, Neufeld G, Gitay-Goren H \& Keshet E 1993 Patterns of expression of vascular endothelial growth factor (VEGF) and VEGF receptors in mice suggest a role in hormonally regulated angiogenesis. Journal of Clinical Investigation 91 2235-2243.

Soh EY, Sobhi SA, Wong MG, Meng G, Siperstein AE, Clark OH \& Duh Q-Y 1996 Thyroid-stimulating hormone promotes the secretion of vascular endothelial growth factor in thyroid cancer cell lines. Surgery 120 944-947.
Sone H, Okuda Y, Kawakami Y, Kondo S, Hanatani M, Matsuo K, Suzuki H \& Yamashita K 1996 Progesterone induces vascular endothelial growth factor on retinal pigment epithelial cells in culture. Life Sciences 59 21-25.

Ueta Y, Levy A, Chowdrey HS \& Lightman SL 1995 S-100 antigen-positive folliculostellate cells are not the source of IL-6 gene expression in human pituitary adenomas. Journal of Neuroendocrinology 7 467-474.

Vankelecom H, Carmeliet P, Van Damme J, Billiau A \& Denef C 1989 Production of interleukin-6 by folliculo-stellate cells of the anterior pituitary gland in a histiotypic cell aggregate culture system. Neuroendocrinology 49 102-106.

Wilting J \& Christ B 1996 Embryogenic angiogenesis: a review. Naturwissenschaften 83 153-164.

Received 1 June 1998

Revised manuscript received 7 October 1998 Accepted 3 November 1998 